
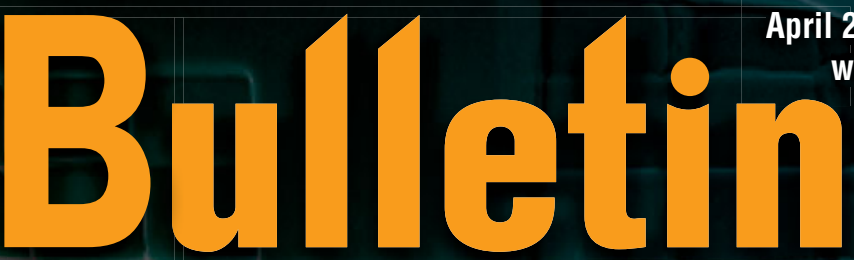

$M|R| S$ MATERIALS RESEARCH SOCIETY

I $S$ Advancing materials. Improving the quality of life.

\title{
Focused ion beam technology
}

www.mrs.org/bulletin

and and applications

ALSO IN THIS ISSUE

Is silicene the next graphene? 


\section{CUSTOMIZED PRODUCTION ION IMPLANTERS}

- Beam energies from $10 \mathrm{keV}$ up to several $10 \mathrm{~s}$ of MeV

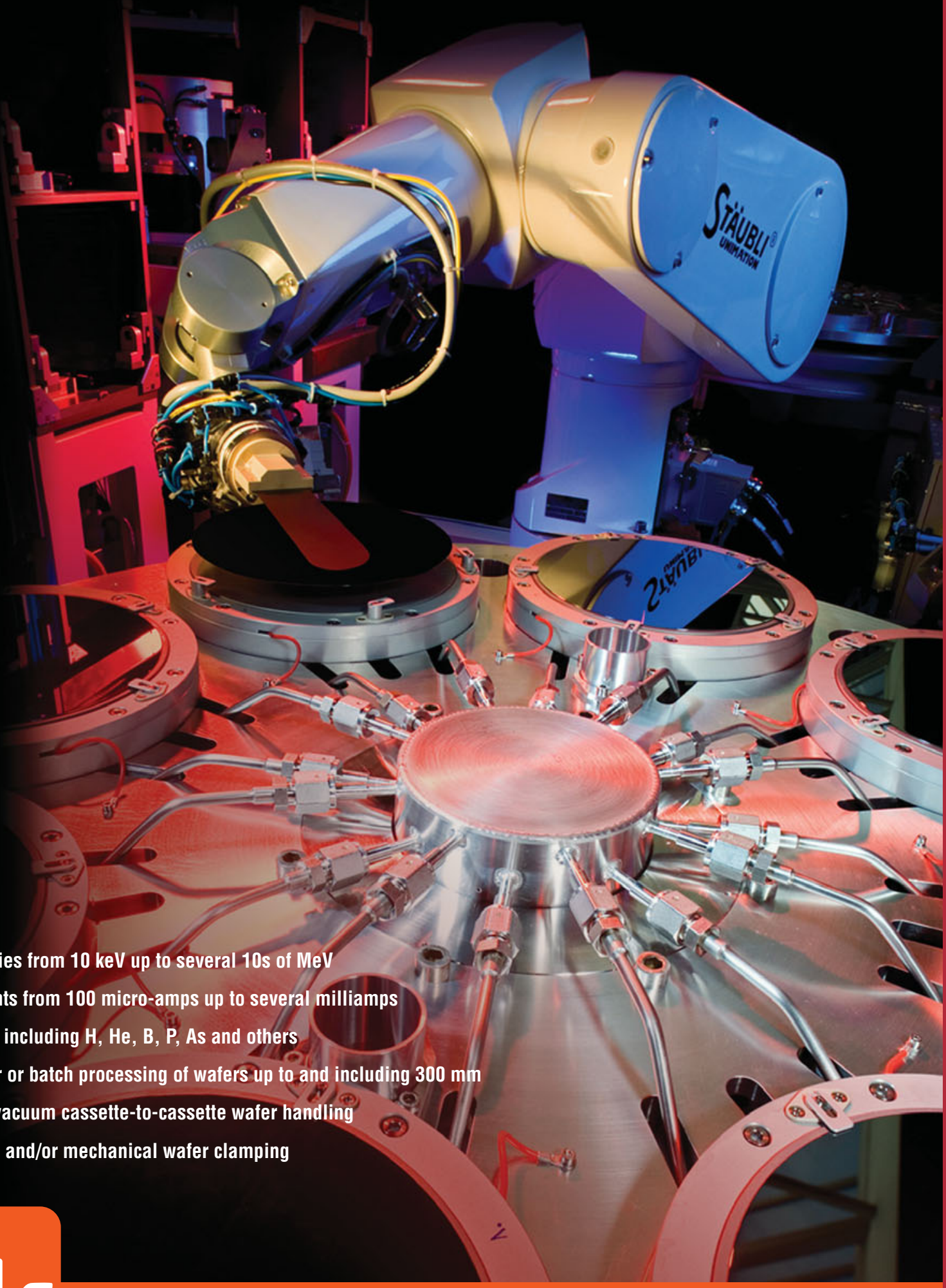

- Beam currents from 100 micro-amps up to several milliamps

- Ion species, including H, He, B, P, As and others

- Single wafer or batch processing of wafers up to and including $300 \mathrm{~mm}$

In-air or in-vacuum cassette-to-cassette wafer handling

- Electrostatic and/or mechanical wafer clamping

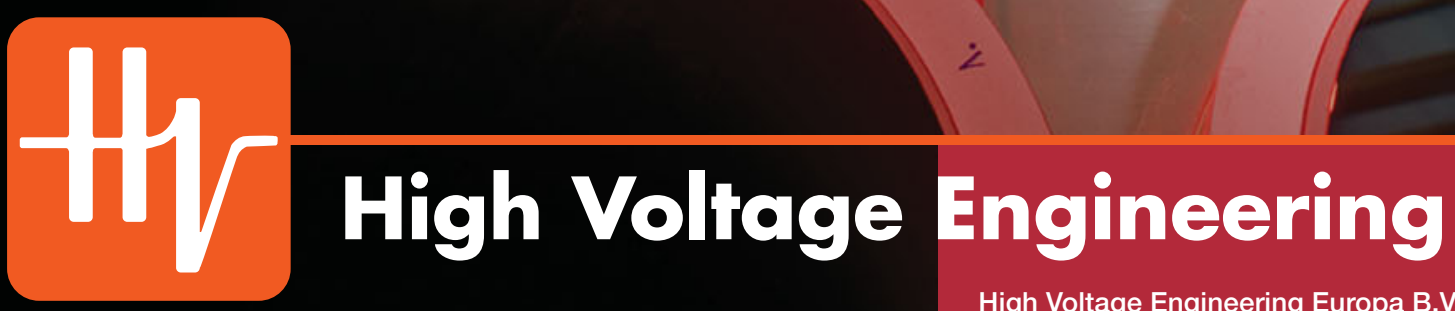

High Voltage Engineering Europa B.V.

P.O. Box 99, 3800 AB Amersfoort, The Netherlands

Tel: $31334619741 \cdot$ info@highvolteng.com

www.highvolteng.com 


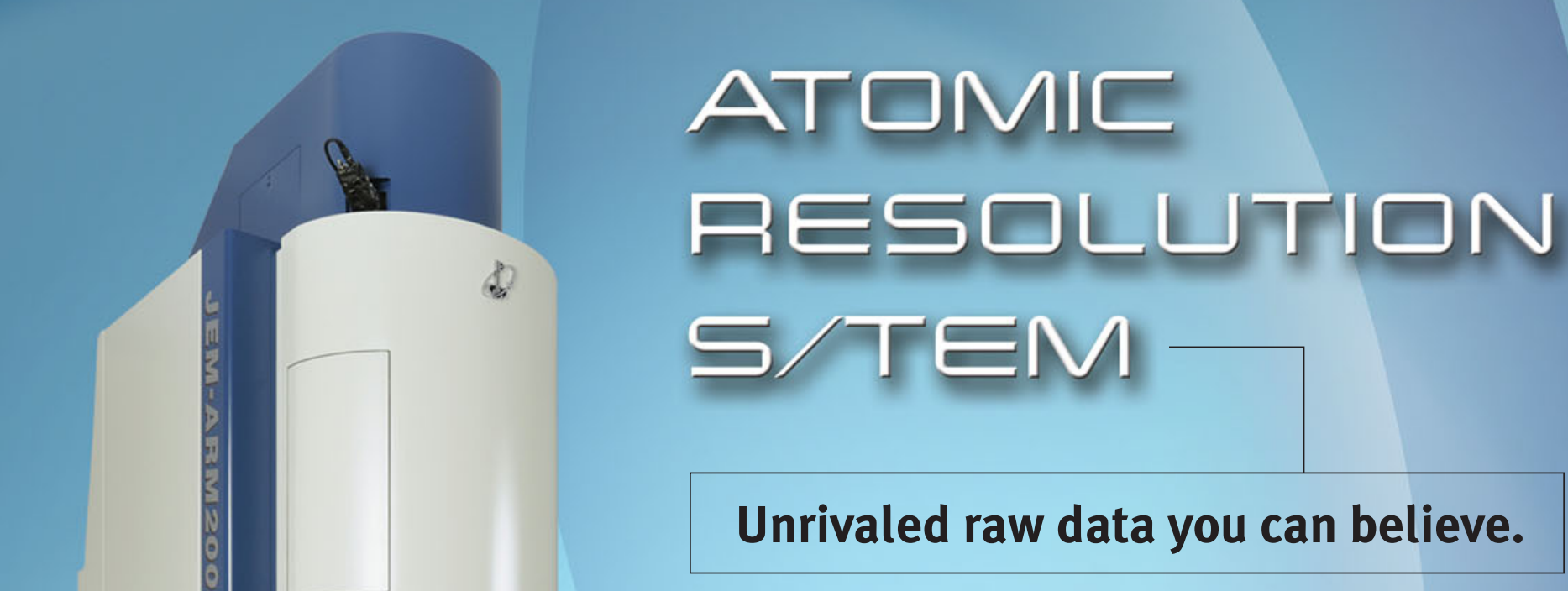

Atom-by-atom sub-angstrom imaging resolution, atom-to-atom chemical mapping, aberration correction, 2 and 3-D reconstruction, and optional Cold FEG. What can we help you achieve?

Dr. John Bradley

University of Hawaii

Commercial NCM Cathode Material for

Li-Ion Batteries. Atomic EDS map. Overlay

shows O (red), Ni (blue), Mn (green).

$0.5 \mathrm{~nm}$

Dr. Miguel Jose Yacaman

University of Texas, San Antonio

Sample provided by Tour Lab, Rice University Chiral Nanotube with parameters $n=10$ and $m=4$ (simulated and experimental).

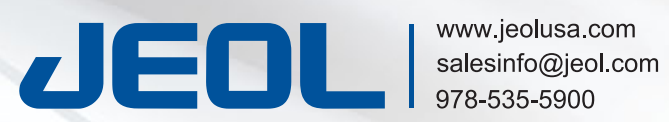

$0.5 \mathrm{~nm}$

\section{Solutions for Innovation}

\section{Dr. Moon Kim}

University of Texas, Dallas

STEM HAADF image of transferred $\mathrm{MoS}_{2}$, showing Mo and $S$ atom positions and their $2 \mathrm{H}$ stacking sequence.

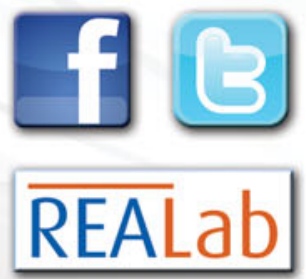




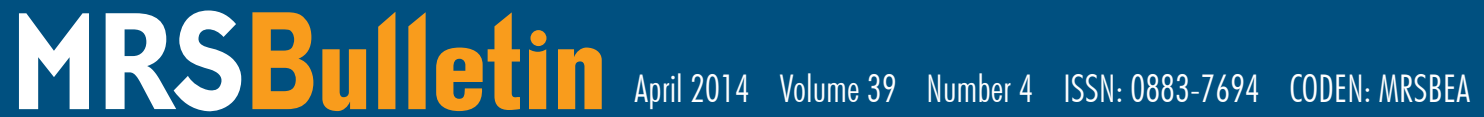
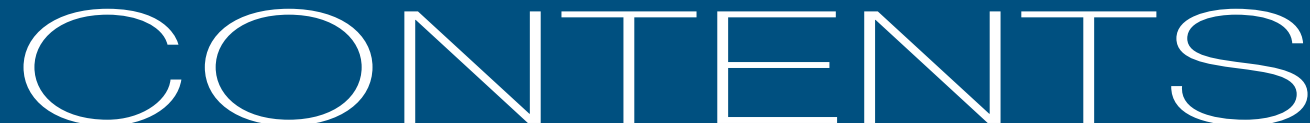

\section{FOCUSED ION BEAM TECHNOLOGY AND APPLICATIONS}

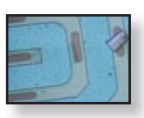

317 Recent advances in focused ion beam technology and applications

Nabil Bassim, Keana Scott, and Lucille A. Giannuzzi, Guest Editors

\section{Meet Our Authors}

329 Advances in source technology for focused ion beam instruments

Noel S. Smith, John A. Notte, and Adam V. Steele

336 High-resolution direct-write patterning using focused ion beams

Leonidas E. Ocola, Chad Rue, and Diederik Maas

342 Modeling ion-solid interactions for imaging applications

D.C. Joy and J.R. Michael

347 In situ FIB-SEM characterization and manipulation methods

Nicholas Antoniou, Konrad Rykaczewski, and Michael D. Uchic

354 Advances in 3D focused ion beam tomography Marco Cantoni and Lorenz Holzer

361 Focused ion beam and scanning electron microscopy for 3D materials characterization Paul G. Kotula, Gregory S. Rohrer, and Michael P. Marsh

\section{TECHNICAL FEATURE}

366 Is silicene the next graphene?

L.C. Lew Yan Voon and G.G. Guzmán-Verri

\section{DEPARTMENTS}

\section{NEWS \& ANALYSIS}

\section{Materials News}

- Resonant scattering from silver nanoparticles enhances transparent display performance Tim Palucka

- Turkey skin inspires biomimetic sensor Laurel Hamers

- Light converts monomers into large single-crystal linear polymers Jen Gordon

- Thermal interface resistance of CNT arrays reduced by factor of six Benjamin Scheiner

- Integrated photonic microstructure enables highly directional emission from Eu OLED Colin McCormick

\section{Science Policy}

- NSF focuses on sustainability funding Jennifer A. Nekuda Malik

- Korea reports on 2012 R\&D investments by private companies

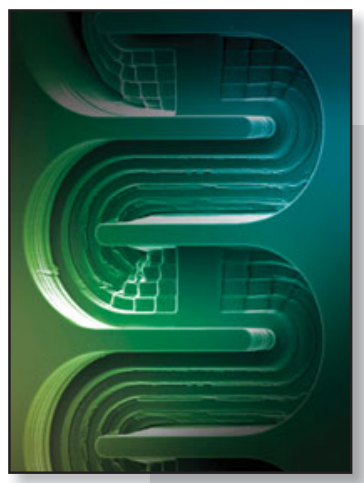

\section{ON THE COVER}

Focused ion beam technology and applications. Focused ion beam (FIB) microscopes coupled with a scanning electron microscope (SEM) offer the opportunity for novel sample imaging, sectioning, specimen preparation, three-dimensional nano- to macroscale tomography, and high resolution rapid prototyping. The articles in this issue of MRS Bulletin feature the state of the art in FIB technology and its applications in materials research, providing insights into future potential for materials characterization and processing using FIBs. The cover image shows a three-dimensional view of FIB-patterned silicon milled for a microfluidic serpentine mixer application. Image courtesy of the American Vacuum Society. See the technical theme that begins on page $\mathbf{3 1 7}$. 


\section{FEATURES}

315 Beyond the Lab

Materials researchers take the stage

Prachi Patel

379 Books

Atomic Force Microscopy

Peter Eaton and Paul West

Reviewed by Igor Sokolov

384 Image Gallery

Look Again

\section{SOCIETY NEWS}

- Albert Polman to receive MRS Innovation in Materials Characterization Award

- Lei Jiang to receive Mid-Career Researcher Award for bioinspired materials

- Henry J. Snaith named 2014 MRS Outstanding Young Investigator for perovskite hybrid solar cells

- Yury Gogotsi to present Kavli Lecture on nanoscience at 2014 MRS Spring Meeting

- Big Data sessions bring variety of opinions Lori A. Wilson

- MRS and E-MRS organize summer school on materials for renewable energy

\section{ADVERTISERS IN THIS ISSUE}

Page No.

American Elements

High Voltage Engineering.

Outside back cover

Hindawi Publishing Corporation ............. Inside back cove Inside front cover

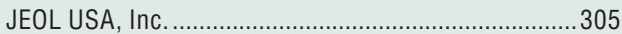

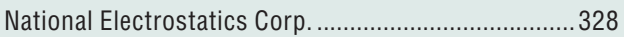

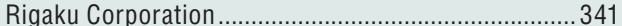

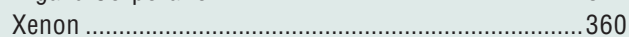

\section{www.mrs.org/bulletin}

MRS members-access MRS Bulletin online

www.mrs.org/energy-quarterly

Access Energy Quarterly online

\section{www.mrs.org/mymrs}

MRS Publications Alert-

receive advance Table of Contents by email

http://journals.cambridge.org/

mrsbulletin-rss

Subscribe TODAY to the MRS Bulletin RSS Feed

Design images used under license from Shutterstock.com 


\section{About the Materials Research Society}

The Materials Research Society (MRS), a not-for-profit scientific association founded in 1973 and headquartered in Warrendale, Pennsylvania, USA, promotes interdisciplinary materials research. Today, MRS is a growing, vibrant, member-driven organization of over 16,000 materials researchers spanning over 80 countries, from academia, industry, and government, and a recognized leader in the advancement of interdisciplinary materials research.

The Society's interdisciplinary approach differs from that of single-discipline professional societies because it promotes information exchange across many scientific and technical fields touching materials development. MRS conducts three major international annual meetings encompassing approximately 125 topical symposia, and also sponsors numerous single-topic scientific meetings. The Society recognizes professional and technical excellence and fosters technical interaction through University Chapters. In the international arena, MRS implements bilateral projects with partner organizations to benefit the worldwide materials community. The Materials Research Society Foundation helps the Society advance its mission by supporting various projects and initiatives.

MRS publishes MRS Bulletin, MRS Communications, the MRS Online Proceedings Library, Journal of Materials Research, MRS Energy \& Sustainability, and books and textbooks with its publishing partner, Cambridge University Press.

\section{MRS BOARD OF DIRECTORS}

President Tia Benson Tolle, The Boeing Company, USA Immediate Past President Orlando Auciello, University of Texas at Dallas, USA

Vice President and President-Elect Oliver Kraft, Karlsruhe Institute of Technology, Germany

Secretary Sean J. Hearne, Sandia National Laboratories, USA

Treasurer Michael R. Fitzsimmons, Los Alamos National Laboratory, USA

Executive Director Todd M. Osman, Materials Research Society, USA

Shenda M. Baker, Synedgen, Inc./Harvey Mudd College, USA

Alexandra Boltasseva, Purdue University, USA

C. Jeffrey Brinker, Sandia National Laboratories and University of New Mexico, USA

David Cahen, Weizmann Institute of Science, Israel

Steve Eglash, Stanford University, USA

Chang-Beom Eom, University of Wisconsin-Madison, USA

Susan Ermer, Lockheed Martin Advanced Technology Center, USA

Eric Garfunkel, Rutgers University, USA

Sossina M. Haile, California Institute of Technology, USA

Andrea M. Hodge, University of Southern California, USA

Hideo Hosono, Tokyo Institute of Technology, Japan

Fiona C. Meldrum, University of Leeds, UK

Kornelius Nielsch, University of Hamburg, Germany

Eric A. Stach, Brookhaven National Laboratory, USA

Stephen Streiffer, Argonne National Laboratory, USA

Loucas Tsakalakos, General Electric-Global Research Center, USA

MRS OPERATING COMMITTEE CHAIRS

Academic Affairs Bruce Clemens, Stanford University, USA

Awards C. Barry Carter, University of Connecticut, USA

Government Affairs Nabil Bassim, US Naval Research Laboratory, USA

Meetings Committee David S. Ginley, National Renewable Energy Laboratory, USA

Member Engagement Yves Chabal, The University of Texas at Dallas, USA Public Outreach Aditi Risbud, University of Utah in Salt Lake City, USA

Publications Susan Trolier-McKinstry (Acting Chair), The Pennsylvania State University, USA

MRS OFFICE OF PUBLIC AFFAIRS

Ron Kelley 499 South Capitol St. SW, Suite 600, Washington, DC 20003
EDITORIAL OFFICE 506 Keystone Drive, Warrendale, PA 15086-7573 USA Bulletin@mrs.org tel 724.779.2747 fax 724.779.8313 www.mrs.org
Editor

Gopal R. Rao, rao@mrs.org

Managing Editor

Judy Meiksin, meiksin@mrs.org

Technical Editor

Lori A. Wilson, Iwilson@mrs.org

Editorial Assistants

Michelle S. Raley, raley@mrs.org

Mary Wilmoth

Associate Technical Editor

B. Reeja Jayan

Production/Design

Andrea Pekelnicky, Felicia Turano,

Rebecca Yokum, and TNQ

Production Editor

Catherine Paduani

Science News Editor

Tim Palucka

Principal Development Editor

Elizabeth L. Fleischer

Director of Communications

Eileen Kiley Novak

\section{Guest Editors}

Nabil Bassim, Keana Scott, and Lucille A. Giannuzz

Energy Quarterly

Anke Weidenkaff (Chair) Anshu Bharadwaj, David Cahen, Russell R. Chianelli, George Crabtree, Sabrina Sartori, M. Stanley Whittingham, and Steve M. Yalisove

Advertising/Sponsorship

Mary E. Kaufold, kaufold@mrs.org

Donna L. Watterson, watterson@mrs.org

Member Subscriptions

Michelle Judt, judt@mrs.org

Non-Member Subscriptions

subscriptions_newyork@cambridge.org

\section{EDITORIAL BOARD}

Paul S. Drzaic (Chair), Apple, Inc., USA

V.S. Arunachalam, Center for Study of Science, Technology \& Policy, India

Marie-Isabelle Baraton, University of Limoges, France

Hanns-Ulrich Habermeier, Max Planck Institute for Solid State Research, Germany

Igor Lubomirsky, Weizmann Institute, Israel

Fiona C. Meldrum, University of Leeds, UK

Amit Misra, Los Alamos National Laboratory, USA

Steven C. Moss, Aerospace Corporation, USA

Julie A. Nucci, Cornell University, USA

Linda J. Olafsen, Baylor University, USA

James W. Stasiak, Hewlett-Packard Co., USA

Carol Trager-Cowan, University of Strathclyde, UK

Anke Weidenkaff, University of Stuttgart, Germany

Eric Werwa, Washington, DC, USA

Steve M. Yalisove, University of Michigan, USA

\section{VOLUME ORGANIZERS}

2015 Ying-Hao (Eddie) Chu, National Chiao Tung University, Taiwan Kalpana S. Katti, North Dakota State University, USA

Tommie W. Kelley, 3M, USA

Jud Ready, Georgia Institute of Technology, USA

2014 Deborah E. Leckband, University of Illinois at Urbana-Champaign, USA Yuri Suzuki, Stanford University, USA

Enrico Traversa, King Abdullah University of Science and Technology, Saudi Arabia Yonhua Tzeng, National Cheng Kung University, Taiwan

2013 Mark T. Lusk, Colorado School of Mines, USA Eva Olsson, Chalmers University of Technology, Sweden Birgit Schwenzer, Pacific Northwest National Laboratory, USA James W. Stasiak, Hewlett-Packard Co., USA Materials Research Society. Permission required to reproduce content. Periodical postage paid at New York, NY, and at additional mailing offices. POSTMASTER: Send address changes to MRS Bulletin in care of the Journals Department, Cambridge University Press, 100 Brook Hill Drive, West Nyack, NY 10994-2113, USA. Printed in the U.S.A.

Membership in MRS is $\$ 115$ annually for regular members, $\$ 30$ for students. Dues include an allocation of $\$ 29$ ( $\$ 17$ for students) to a subscription to MRS Bulletin. Individual member subscriptions are for personal use only. Non-member subscription rates are $\$ 439$ for one calendar year (12 issues) within North America and $\$ 527$ elsewhere. Requests from subscribers for missing journal issues will be honored without charge only if received within six months of the issue's actual date of publication.

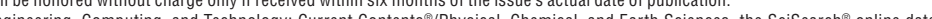
base, Research Alert ${ }^{\oplus}$ Science Citation Index ${ }^{\circledast}$, and the Materials Science Citation IndexTM. Back volumes of MRS Bulletin are available on microfiche through University Microfilms Inc. 300 North Zeeb Road, Ann Arbor, MI 48106, USA. 